\title{
Optimized Utilization of Flyash and Cowdung ash in Enhancing the Properties of Self Compacting Concrete
}

\author{
PL. Meyyappan, B. Jayaprakash
}

\begin{abstract}
In a brief outlook, the conventional concrete has a numerous setbacks in order to congregate the vast demand of the construction industries, regarding the complex construction projects in a stipulated time. Among that, the improper and lack of compaction will leads a key role in affecting the strength and durability characteristics of the concrete in several ways. This issue will be resolved in the existence of the self compacting properties within the concrete. Since the lack of design procedures and mixing guidelines in relevant to Indian standards, many researchers used EFNARC guidelines for their studies. In this paper, the combined effect of the filler materials such as flyash and cowdung ash in satisfying the requirements of SCC is presented for the different replacement levels such as 5\%, 10\%, $15 \%, 20 \%, 25 \%$ and $30 \%$. The optimum combined replacement level is found as $15 \%$ in succeeding the requirements of the filling and passing ability properties of SCC.

Keywords : SCC, EFNARC Guidelines, Concrete, Strength
\end{abstract}

\section{INTRODUCTION}

In view of the construction industry, there is a huge demand for the construction of large and complex structure. While addressing these demands, the conventional concrete needs to have large and multifarious concrete reinforcements. During the process of mass concreting, the conventional concrete has the prime issues in the compaction stage, where sometimes it will be improper or difficult to proceed. This leads to the adverse effect in the strength and durability characteristics of the concrete through the cause of honey combing, bleeding, segregation etc. In order to overcome

these issues, the concrete should be flow on its own self weight and to pack the entire volume of the form work area with its constituents without the support of any external compaction device. This described property leads a development 'Self compacting concrete' (SCC) in old 1980's and introduced in Japan [10]. In India, the development of SCC is still not favorably used due to the absence of describing the specifications and mixing guidelines related to Indian Standards [9] [4]. Most of the researchers used EFNARC guidelines in a trial and error basis for finding the suitable SCC mix proportions in satisfying the passing ability and filling ability properties [4], [5], [9], [10]. In many researches, rubber waste, plastic waste, recycled aggregates, flyash, slag and silica fume, fibres etc are used as the

Revised Manuscript Received on December 30, 2019.

* Correspondence Author

PL. Meyyappan*, Civil department, Kalasalingam Academy of Research and Education, Krishnankoil, India. Email: meyyappan@klu.ac.in B.Jayaprakash, QA/QC Engineer, L\&T Construction, Mumbai, India. Email: jayaprakash.b3112@gmail.com replacement materials in SCC [3], [4], [6], [7], [11] However, the combined effect of the materials in SCC is still in inception. Hence, in this paper an attempt is made to study the combined effect of flyash and cowdung in developing the mix proportion of SCC and its strength characteristics.

\section{MATERIAL USED}

The following constituent materials are used in this experimental study.

\section{A. Cement}

Ordinary Portland cement (OPC) of 43 grade confirming to the standards of IS: 8112-2013.

\section{B. Fine aggregate}

River sand is used as fine aggregate with the specific gravity of 2.63. It is confirming to zone II of IS $382-2016$. Its fineness modulus is 3.85 .

\section{Coarse aggregate}

Crushed coarse aggregate of size $12.5 \mathrm{~mm}$ with a specific gravity of 2.8 is used. Its fineness modulus is 4.6.

\section{Flyash}

Class C flyash with a specific gravity 2.38 obtained from Tuticorin Thermal Power Station is used for the replacement of cement in different levels.

\section{E. Cowdung ash}

Pulverized cowdung ashes sieved through 300 microns are used and its specific gravity is 2.59 .

\section{F. Chemical admixture}

A high range water reducing admixture, Tec MIX 550 is used.

\section{G. Water}

Potable drinking water is used for mixing SCC and curing purpose.

\section{TRIAL MIX PROPORTION}

Many researchers used a trial and error based mix proportion for the SCC based on the EFNARC guidelines, Since there is no separate IS mix design procedures / guidelines are available. 


\section{Optimized Utilization of Flyash and Cowdung ash in Enhancing the Properties of Self Compacting Concrete}

For the initial SCC mix design, three workability test namely slump test, V-funnel test and L-box test are conducted to satisfy the properties of filling ability and passing ability. For slump test, the acceptable range of values are $650 \mathrm{~mm}$ to $800 \mathrm{~mm}$, similarly for V-funnel and L-Box test, the ranges are $6 \mathrm{sec}$ to $12 \mathrm{sec}$ and 0.8 to 1.0 respectively. Based on the literatures, a initial trial mix of 1 (Cement) : $1.48(\mathrm{FA}): 1.52(\mathrm{CA}): 0.46(\mathrm{~W} / \mathrm{c})$ with super plasticizer $1.14 \%$ is adopted and the above mentioned workability tests are conducted. The ingredient materials are increased or decreased till it satisfies the requirements of EFNARC guidelines. The SCC mix proportion (Trial 9) is arrived based on the satisfactory requirements of EFNARC guidelines among the various trials conducted as indicated in Table 2. Therefore the final SCC design mix is $1: 1.53: 1.02: 0.43$ with $2.5 \%$ of super plasticizer.

Table- I: Trial Mix Proportion for SCC

\begin{tabular}{|c|c|c|c|c|c|c|}
\hline Mix & $\begin{array}{l}\text { Cement } \\
(\mathrm{Kg} / \mathrm{m} 3)\end{array}$ & $\begin{array}{c}\text { F.A } \\
(\mathrm{Kg} / \mathrm{m} 3)\end{array}$ & $\begin{array}{c}\text { C.A } \\
(\mathrm{Kg} / \mathrm{m} 3)\end{array}$ & $\begin{array}{c}\text { Water } \\
(\mathrm{Kg} / \mathrm{m} 3)\end{array}$ & $\begin{array}{l}\text { S.P } \\
(\%)\end{array}$ & Remarks \\
\hline TR1 & 499 & 743 & 759 & 230 & 1.14 & $\begin{array}{l}\text { Not satisfying the requirements of EFNARC guidelines } \\
\text { due to the cause of segregation. Hence it is decided to } \\
\text { increase the paste volume and super plasticizer. }\end{array}$ \\
\hline TR2 & 510 & 775 & 759 & 250 & 1.5 & $\begin{array}{l}\text { Not satisfying the requirements of EFNARC guidelines } \\
\text { due to the cause of low viscosity. Hence it is decided to } \\
\text { increase the finer sand content without changing the } \\
\text { cement content. }\end{array}$ \\
\hline TR3 & 510 & 775 & 611 & 273 & 1.5 & $\begin{array}{l}\text { Not satisfying the requirements of EFNARC guidelines } \\
\text { due to the cause of blockage. Hence it is decided to } \\
\text { decrease the CA content without changing the cement } \\
\text { content. }\end{array}$ \\
\hline TR4 & 570 & 815 & 625 & 256 & 2.0 & $\begin{array}{l}\text { Not satisfying the requirements of EFNARC guidelines } \\
\text { due to the cause of blockage and high yield value. Hence } \\
\text { it is decided to increase the cement, FA and super } \\
\text { plasticizer content and decrease the water and CA } \\
\text { content. }\end{array}$ \\
\hline TR5 & 570 & 977 & 680 & 243 & 2.0 & $\begin{array}{l}\text { Not satisfying the requirements of EFNARC guidelines } \\
\text { due to the cause of high yield value. Hence it is decided } \\
\text { to increase the FA and CA content and decrease the water } \\
\text { content without changing cement content. }\end{array}$ \\
\hline TR6 & 600 & 977 & 700 & 290 & 2.5 & $\begin{array}{l}\text { Not satisfying the requirements of EFNARC guidelines } \\
\text { due to the cause of high viscosity value. Hence it is } \\
\text { decided to increase the cement, CA, water and super } \\
\text { plasticizer content without changing the FA content. }\end{array}$ \\
\hline TR7 & 666 & 1025 & 710 & 296 & 2.5 & $\begin{array}{l}\text { Not satisfying the requirements of EFNARC guidelines } \\
\text { due to the cause of high viscosity value and yield value. } \\
\text { Hence it is decided to increase the cement, FA, CA and } \\
\text { water without changing super plasticizer content. }\end{array}$ \\
\hline TR8 & 700 & 1072 & 715 & 300 & 2.5 & $\begin{array}{l}\text { Slight differences in filling and passing ability test and it } \\
\text { is merely in the border range to satisfying the } \\
\text { requirements of EFNARC. Hence it is decided to slightly } \\
\text { increase the paste volume without changing super } \\
\text { plasticizer content. }\end{array}$ \\
\hline TR9 & 700 & 1072 & 715 & 304 & 2.5 & $\begin{array}{l}\text { The mix proportions satisfied requirements of EFNARC } \\
\text { guidelines. The values of filling and passing ability test } \\
\text { are well in the acceptable range. }\end{array}$ \\
\hline TR10 & 700 & 1072 & 715 & 315 & 2.5 & $\begin{array}{l}\text { The mix proportions satisfied requirements of EFNARC } \\
\text { guidelines with the maximum acceptable range in the } \\
\text { filling and passing ability tests. }\end{array}$ \\
\hline
\end{tabular}

\section{EXPERIMENTAL STUDY}

Based on the SCC mix proportions arrived, the further experimental work is continued to replace the cement by the flyash and cowdung ash materials in the replacement levels $5 \%, 10 \%, 15 \%, 20 \%$, 
$25 \%, 30 \%$ by weight fraction either in a individual or in a combined way. The fresh and hardened concrete tests are conducted to find the optimum replacement level in satisfying the requirements of SCC and its strength. Slump flow test, T50cm slump flow test, V-funnel test and L box test are conducted for the study of fresh concrete properties of SCC and acceptance range of values to satisfy the properties of SCC are discussed in the trial mix

proportion section. Cubes of size $150 \mathrm{~mm}$ x $150 \mathrm{~mm}$ x 150 $\mathrm{mm}$ and cylinders of size $300 \mathrm{~cm}$ and $150 \mathrm{~cm}$ are casted for all the replacement levels of SCC specimens to evaluate the compressive strength and split tensile strength test respectively.

\section{RESULTS AND DISCUSSION}

\section{A. Test on fresh concrete properties on SCC}

Figure 1 (a) - (c) shows the working photographs of the slump flow test, V-funnel test and L-box test conducted on the SCC trials. In slump flow test, slump flow diameter is measured in terms of ' $\mathrm{mm}$ ' and $\mathrm{T} 50 \mathrm{~cm}$ slump flow time is observed in terms of 'seconds'. Similarly, V-funnel flow time is observed in terms of 'seconds' and the blocking ratio is calculated from $\mathrm{H} 2 / \mathrm{H} 1$ respectively. All fresh concrete test results are tabulated in the first part of table 2 with respective replacement levels of flyash and cowdung ash. In Table 2, the bolded values indicating that, it is satisfying the requirements/ranges as described in EFNARC guidelines. In flyash replacements, except $\mathrm{V}$-funnel test, $15 \%$ replacement shows the performance of SCC and fresh concrete properties are better than other replacements. Even though the $\mathrm{V}$-funnel flow time is well within the range for $25 \%$ replacements, in comparing the characteristics property of filling ability and passing ability, SCC behavior satisfies the replacements in the range of $5 \%$ to $15 \%$. In that range, the slump flow diameter is in between $700 \mathrm{~mm}$ to $740 \mathrm{~mm}$, L-box ratio is in between 0.80 to 0.87 and T50 slump flow time is in between 3 to 4 . Beyond in the increase of replacement levels, it is observed that, the range values becomes less which is clearly indicating, the corresponding mix is having too high viscosity and yield value. In cowdung ash replacements, all the test results showing the decreasing trend. The SCC behavior is found only in the replacements of $5 \%$ and $10 \%$ and that is also found only in the minimum range. Beyond the increase of cowdung ash replacements, will have a blockage effect. Interestingly, if cowdung ash is combined with flyash in a equal proportion, it is observed that the blockage effect is minimized, viscosity and yield values are well within the range for even $15 \%$ replacements.

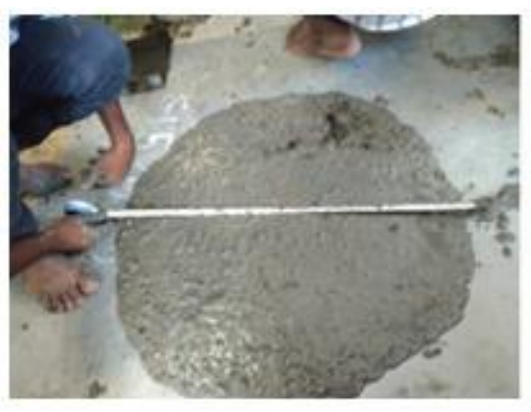

(a) Slump flow test

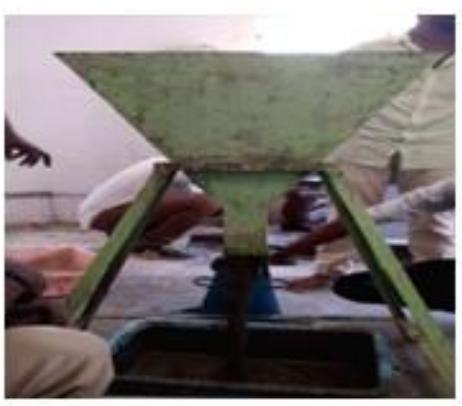

(b) V-funnel test

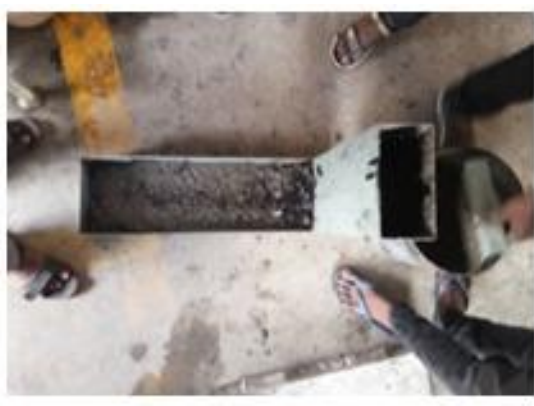

(c) L-box test

Fig. 1.(a) - (c) Fresh concrete test on SCC

\section{B. Test on hardened concrete properties on SCC}

In Table 2, the second part, indicating the test results of hardened concrete of different replacements of flyash and cowdung ash on the SCC trials. The maximum compressive strength and split tensile strength is found as $37.86 \mathrm{~N} / \mathrm{mm} 2$ and $5.77 \mathrm{~N} / \mathrm{mm} 2$ respectively for the replacement levels $20 \%$. The gain factor is around $18 \%$. For beyond the replacements $25 \%$ and $30 \%$, the strength values are in the decreasing trend, since the lack of proportion of the binding property with a losing factor of $14 \%$ strength. In all cowdung ash replacements, it is found that, the compressive strength and split tensile strength is decreased in comparison with the control specimen upto 50\% strength reduction. For $5 \%$ replacement, the strength loss factor is around $10 \%$ and successive replacements will have the proportionate decreasing trend. The reason is that, the cowdung ash is not participating with the exothermic reaction with the cement mix, which remains as just like a filler material. If the replacements materials flyash and cowdung ash is mixed in an equal proportion, the strength is slight getting increasing with a gain factor of $3 \%$ on the combined replacements at $10 \%$. The optimum replacement percentage is on $15 \%$ with a gain factor of $7 \%$ increase in the strength.

The performance of cowdung ash in related with the strength is enhanced with the addition of flyash with the gaining factor of $25 \%$. This combined all replacement levels seems to be effective and in the increasing trend in comparing with the individual performance of cowdung ash.

\section{CONCLUSION}

The following conclusions are arrived based on the experimental work:

1. Since no Indian guidelines are available to arrive the mix design for SCC, a trial and error method is used 
Optimized Utilization of Flyash and Cowdung ash in Enhancing the Properties of Self Compacting Concrete

based on the EFNARC specifications / requirements. The most suited mix proportion arrived in the experimental work is $1: 1.53: 1.02$ (W/c Ratio 0.43)

2. In order to optimize the cost factor and effective handling of waste products, the cement content can be reduced by effectively utilizing the replacement materials such as flyash and Cowdung ash (CDA) in SCC. In this experimental study it is inferred that flyash and cowdung ash is blend well and thereby some workability is achieved, which is one of the prime factors of SCC.

3. By utilizing fly ash alone in to the concrete, the compressive strength is increased by $17 \%$. When cow dung ash is included as a individual replacement material, the compressive strength is decreased for all replacements levels. If fly ash and cow dung ash is replaced in a combined manner, the strength is increased by around $8 \%$.

4. For the fresh concrete, the SCC behavior is satisfied in the $20 \%$ replacement levels for flyash, $10 \%$ for cowdung ash and $15 \%$ for combined flyash and cowdung ash replacements. When it is replaced beyond that, the strength is decreased due to the absence of binder material.

Table- II: Test results on fresh \& hardened SCC for different replacements levels of flyash and cowdung ash

\begin{tabular}{|c|c|c|c|c|c|c|c|c|c|c|}
\hline \multirow[b]{2}{*}{ Trials } & \multicolumn{2}{|c|}{ Replacements } & \multicolumn{6}{|c|}{ Test on Fresh Concrete } & \multicolumn{2}{|c|}{ Test on Hardened Concrete } \\
\hline & $\begin{array}{l}\text { FA } \\
\text { (\%) }\end{array}$ & $\begin{array}{l}\text { CDA } \\
(\%)\end{array}$ & $\begin{array}{c}\mathrm{H} 1 \\
(\mathrm{~mm})\end{array}$ & $\begin{array}{c}\mathrm{H} 2 \\
(\mathrm{~mm})\end{array}$ & $\begin{array}{l}\text { L box } \\
\text { ratio }\end{array}$ & $\begin{array}{c}\text { V-funnel } \\
\text { flow time } \\
\text { (Sec) }\end{array}$ & $\begin{array}{l}\text { Slump flow } \\
\text { diameter } \\
(\mathrm{mm})\end{array}$ & $\begin{array}{l}\text { T50 Slump } \\
\text { flow time } \\
\text { (Sec) }\end{array}$ & $\begin{array}{c}\text { Compressive } \\
\text { strength Test } \\
\left(\mathrm{N} / \mathrm{mm}^{2}\right)\end{array}$ & $\begin{array}{c}\text { Split tensile } \\
\text { strength test } \\
\left(\mathrm{N} / \mathrm{mm}^{2}\right)\end{array}$ \\
\hline 1 & 0 & 0 & 11.6 & 10.6 & 0.91 & 11 & 760 & 4 & 31.51 & 4.74 \\
\hline 2 & 5 & 0 & 10.1 & 8.8 & 0.87 & 11 & 740 & 4 & 33.32 & 5.06 \\
\hline 3 & 10 & 0 & 10.2 & 8.7 & 0.85 & 10 & 730 & 3 & 35.76 & 5.21 \\
\hline 4 & 15 & 0 & 10.7 & 8.6 & 0.80 & 10 & 700 & 3 & 36.08 & 5.32 \\
\hline 5 & 20 & 0 & 11.3 & 8.3 & 0.74 & 8 & 640 & 2 & 37.86 & 5.77 \\
\hline 6 & 25 & 0 & 13.2 & 9.6 & 0.73 & 7 & 610 & 2 & 31.52 & 4.59 \\
\hline 7 & 30 & 0 & 13.2 & 9.6 & 0.73 & 5 & 590 & 1 & 27.36 & 4.17 \\
\hline 8 & 0 & 5 & 10.2 & 8.7 & 0.85 & 10 & 730 & 3 & 28.35 & 4.32 \\
\hline 9 & 0 & 10 & 11.3 & 9.2 & 0.81 & 8 & 690 & 3 & 26.78 & 3.98 \\
\hline 10 & 0 & 15 & 11.4 & 9 & 0.78 & 8 & 630 & 2 & 24.92 & 3.74 \\
\hline 11 & 0 & 20 & 11.4 & 8.9 & 0.71 & 6 & 610 & 1 & 22.35 & 3.23 \\
\hline 12 & 0 & 25 & 12 & 8.3 & 0.69 & 5 & 590 & 1 & 20.82 & 3.15 \\
\hline 13 & 0 & 30 & 12.6 & 8.3 & 0.65 & 4 & 545 & 1 & 15.32 & 2.29 \\
\hline 14 & 2.5 & 2.5 & 10.6 & 9.2 & 0.86 & 10 & 730 & 4 & 30.90 & 4.61 \\
\hline 15 & 5 & 5 & 10.7 & 9.2 & 0.91 & 10 & 700 & 3 & 32.17 & 4.82 \\
\hline 16 & 7.5 & 7.5 & 10.9 & 9 & 0.83 & 9 & 665 & 2 & 33.58 & 5.24 \\
\hline 17 & 10 & 10 & 11.5 & 8.8 & 0.78 & 7 & 610 & 2 & 31.29 & 4.67 \\
\hline
\end{tabular}




\begin{tabular}{|c|c|c|c|c|c|c|c|c|c|c|}
\hline 18 & 12.5 & 12.5 & 11.7 & 8.3 & 0.71 & 5 & 600 & 1 & 25.89 & 3.94 \\
\hline 19 & 15 & 15 & 12.1 & 8.2 & $0 . .68$ & 3 & 570 & 1 & 22.41 & 3.37 \\
\hline
\end{tabular}

\section{REFERENCES}

1. Duna Samson, Omoniyi Tope Moses (2014), "Investigating the Pozzolanic Potentials of Cow dung Ash in Cement Paste and Mortars" Civil and Environmental Research, Vol.6, No.8.

2. Inderveer Singh Gurjar, Gautam Bhadouriya, (2015) "A Study on Use of Cowdung ash and Rice Husk ash in Concrete" International Journal of Research in Engineering and Technology, pp 306 - 310.

3. Jitender Kumar Dhaka, Surendra Roy (2015), "Utilization of fly ash and cow dung ash as partial replacement of cement in concrete" International Journal of Civil and Structural Engineering, Vol.6. pp 23-28.

4. Kumar Satish, Sanjay Kumar, Baboo Rai (2017), "Self Compacting Concrete Using Fly Ash and Silica Fumes as Pozzolanic Material" Vol. 6, No. 2, pp.394-407.

5. Mallesh M, Shwetha G C, Reena K, Madhukaran (2015), "Experimental Studies on M30 Grade Self Compacting Concrete" International Journal of Science, Engineering and Technology Research (IJSETR), Vol.4, No. 9.

6. Omoniyi.T, Duna,S and Mohammed .A., (2014), "Compressive strength characteristic of cow dung ash blended cement concrete" International Journal of Scientific \& Engineering Research, vol. 5, No. 7, pp. 770-776.

7. Ojedokun O. Y., A. A. Adeniran, S. B. Raheemand S. J. Aderinto, (2014) "Cow Dung Ash (CDA) as Partial Replacement of Cementing Material in the Production of Concrete" British Journal of Applied Science \& Technology, Vol. 4, No. 24, pp. 3445-3454.

8. The European Guidelines for Self Compacting Concrete (2005), http://www.efnarc.org/pdf/SCCGuidelinesMay2005.pdf.

9. Hemant Sood, R.K. Khitoliya and S.S.Pathak (2009), "Incorporating European Standards for Testing Self Compacting Concrete in Indian Conditions", International Journal of Recent Trends in Engineering, Vol. 1, No.6, pp.41-45.

10. Kshama Shukla and Akansha Tiwari (2017), "Self Compacting Concrete Mix Design for M-30", Vol. 4, No.7, pp. 1832-1835.

11. PL. Meyyappan, K.Kumaran, M.Gopalakrishnan and E. Harikrishnan (2018), "Effect of glass fibers, flyash and quarry ash on Strength and Durability Aspects of Concrete - An Experimental Study", IOP Conference Series: Material Science and Engineering, doi:10.1088/1757-899X/396/1/012001.

12. PL. Meyyappan, K.Kumaran, M.Gopalakrishnan and E. Harikrishnan (2018), "Experimental Investigation on the Effect of Silica fume and Pumice stone in Developing Light Weight Concrete", IOP Conference Series: Material Science and Engineering, doi:10.1088/1757-899X/561/1/012064.

13. PL. Meyyappan, P. Amuthakannan, R. Sutharsan and M. Ahamed Azik Ali (2019), "Utilization of M-Sand \& Basalt Fiber in Concrete: An Experimental Study on Strength and Durability Properties", IOP Conference Series: Material Science and Engineering, doi:10.1088/1757-899X/561/1/012035.

\section{AUTHORS PROFILE}

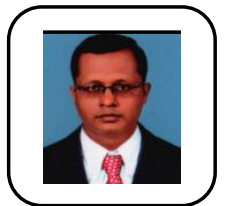

Dr. PL. Meyyappan has completed his graduation and post-graduation from Bharathiyar University and Karunya University respectively. He completed his $\mathrm{PhD}$ from Kalasalingam University. He has 13 years of teaching experience. He has completed 2 sponsored research projects from TNSCST and published more than 25 papers in peer reviewed journals and conferences. He is a life member in ISTE, IEI, IGS, ISET, ISRS. He is serving as Editorial Board Member and Reviewer in various reputed Journals.

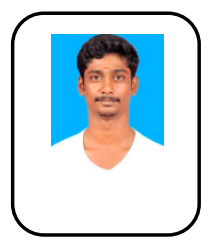

Mr. B. Jayaprakash has completed his B.Tech in Civil Engineering in Kalasalingam Academy of Research and Education, Krishnankoil in the year 2018.. $\mathrm{He}$ is working as QA/QC Engineer in Larsen and Toubro (Powai), Mumbai. 